\title{
Extraction and characterization of pepsin-soluble collagen from different mantis shrimp species
}

\author{
Rachanimuk Hiransuchalert ${ }^{1,2,{ }^{*}}$, Nakaweerada Oonwiset ${ }^{1}$, Yolrawee Imarom ${ }^{1}$, Parinya Chindudsadeegul ${ }^{3}$, \\ Penchan Laongmanee ${ }^{1}$, Sukchai Arnupapboon ${ }^{4}$ \\ ${ }^{1}$ Faculty of Marine Technology, Burapha University Chanthaburi Campus, Chanthaburi 22170, Thailand \\ ${ }^{2}$ Faculty of Science, Burapha University, Chonburi 20131, Thailand \\ ${ }^{3}$ Faculty of Gems, Burapha University Chanthaburi Campus, Chanthaburi 22170, Thailand \\ ${ }^{4}$ Training Department, Southeast Asian Fisheries Development Center, Samut Prakan 10290, Thailand
}

\begin{abstract}
The objective of this study was to investigate the yield and characteristics of collagen protein extracted from the muscle of four different species of mantis shrimp: Miyakella nepa, Harpiosquilla harpax, Erugosquilla woodmasoni, and Odontodactylus cultrifer. Mantis shrimp muscle was extracted by using a pepsin-solubilization technique, with $0.5 \mathrm{M}$ acetic acid and $5 \%$ pepsin enzyme. The highest collagen yield was from $M$. nepa muscle $(0.478 \pm 0.06 \%)$, which was significantly greater $(p<0.05)$ than that from $H$. harpax, O. cultrifer, and $E$. woodmasoni $(0.313 \pm 0.03 \%, 0.123 \pm 0.02 \%$, and $0.015 \pm 0.00 \%$, respectively). The freeze-dried collagen appeared as thin fibers, and formed an opaque film. The pepsin-soluble collagen (PSC) from four mantis shrimp species was analyzed by gel electrophoresis. The results showed that all species of mantis shrimp contained type I collagen, consisting of $\beta$, a1, and $\mathrm{a} 2$ subunits with average molecular weights of 250,145 , and $118 \mathrm{kDa}$, respectively. The study of the solubility of collagen showed that, for $\mathrm{NaCl}$, collagen had the highest relative solubility in $2 \% \mathrm{NaCl}(80.20 \pm 4.95 \%)$. In contrast, the solubility decreased at higher $\mathrm{NaCl}$ concentrations. However, in terms of $\mathrm{pH}$, collagen had the highest relative solubility at pH $3(91.32 \pm 5.14 \%)$, and its solubility decreased at higher $\mathrm{pH}$. FT-IR spectroscopy was used to compare the collagen with a model compound. Five wavenumbers in the spectrum for model collagen were identified: Amide $A\left(3,406-3,421 \mathrm{~cm}^{-1}\right)$, amide $B\left(2,916-2,940 \mathrm{~cm}^{-1}\right)$, amide I $\left(1,639-1,640 \mathrm{~cm}^{-1}\right)$, amide II $\left(1,539-1,570 \mathrm{~cm}^{-1}\right)$, and amide III $\left(1,234-1,250 \mathrm{~cm}^{-1}\right)$.
\end{abstract}

Keywords: Mantis shrimp, Pepsin-soluble collagen, Sodium dodecyl sulfate-polyacrylamide gel electrophoresis (SDS-PAGE), Fourier transform-infrared (FT-IR), Solubility

\section{Introduction}

Collagen is a unique fibrous protein that acts as a key compo- nent of the skeletal structure. It is the most abundant structural protein in the extracellular matrix of the various connective tissues in the body (i.e., skin, bones, ligaments, tendons, and carti-

Received: Oct 5, 2021 Revised: Oct 22, 2021 Accepted: Oct 26, 2021

${ }^{*}$ Corresponding author: Rachanimuk Hiransuchalert

Faculty of Marine Technology, Burapha University Chanthaburi Campus, Chanthaburi 22170, Thailand

Tel: +66869051333, E-mail: rachanimuk@buu.ac.th

This is an Open Access article distributed under the terms of the Creative Commons Attribution Non-Commercial License (http://creativecommons.org/licenses/by$\mathrm{nc} / 4.0 /$ ) which permits unrestricted non-commercial use, distribution, and reproduction in any medium, provided the original work is properly cited.

Copyright $\odot 2021$ The Korean Society of Fisheries and Aquatic Science 
lage), and consists of amino acids, including 33.5\% glycine, $12 \%$ proline, and $10 \%$ hydroxyproline within the polypeptide chain (Shoulders \& Raines, 2009). Hydroxyproline and hydroxylysine are amino acids in collagen that are specifically generated by the hydroxylation of proline and glycine in the polypeptide chain in the rough endoplasmic reticulum (RER) during the synthesis of the protein (Jafari et al., 2020). The concentration of collagen in any organism tissue can therefore be determined by measuring the concentration of hydroxyproline. The collagen monomer, called tropocollagen, is made up of three polypeptide strands wrapped around each other like a strand or triple helix. This is responsible for the different properties of collagen in organism tissues with different form, toughness, and tensile strength (Shoulders \& Raines, 2009). An organism synthesizes collagen to replace the collagen that is degraded by various mechanisms. Upon aging, this balance of this process is lost. There are also other causes of collagen degradation, such as UV rays from sunlight, smoking, stress, and an unhealthy diet (Jafari et al., 2020). Therefore, collagen is a very popular protein in many industries: for foods, supplements, pharmaceuticals, cosmetics, and cosmeceuticals. Industrially, most collagen is derived from the bones and skins of cows and pigs. However, owing to reports of mad cow disease infections and some religious restrictions on pig usage (Sadowska et al., 2003), research into the extraction of collagen from aquatic animals has been explored as a replacement for collagen from livestock animals (Morimura et al., 2002). Collagen extraction from aquatic animals is increasing in popularity and there is high demand for this material from customers.

There are at least 28 types of collagens, which differ in their domain structure and superstructural organization; however, $80 \%-90 \%$ of the collagen in the body is type I, II, or III. The most abundant type of collagen in the body, type I, is found in the bones, skin, tendons, and organs (Meyer, 2019). Collagen from fish skin has the properties of type I collagens, consisting of two $\alpha 1$ chains and one $\alpha 2$ chain, whereas collagen from invertebrates, such as squids, mantis shrimp, marine sponges, and jellyfish, has the main properties of type I collagen as well as other types (Duan et al., 2009). Many studies of collagen from the skin, muscle, or tissues of marine animals have been reported, including in tuna (Ahmed et al., 2019), sole fish (Aseraggodes umbratilis) (Cheng et al., 2017), squid (Loligo vulgaris) (Pati et al., 2010), marine sponges (Axinella cannabina and Suberites carnosus) (Tziveleka et al., 2017), jellyfish (Acromitus hardenbergi) (Khong et al., 2018), and mantis shrimp (Oratosquilla nepa) (Jose et al., 2014).
In Thailand, mantis shrimp is classified as a fishery by-catch animal. Research has shown the possibility of using the main and by-catch crustaceans from fisheries to extract collagen and increase the economic value of the catch (Mizuta et al., 1994). Mantis shrimp is a living marine arthropod found in the sea and brackish water, especially in tropical areas. Their distribution is from the tidal zone to a depth of 1,500 meters. In Thailand, at least 61 species have been reported and consumed. There are only seven economically important species (Tangkrock-olan, 2007). They are in great demand both in Thailand and abroad. At present, the volume for all species of mantis shrimp that are caught from the Thai waters is up to $700-800$ tons per year, with a value of approximately 40 million Thai Baht. The objective of this research was therefore to quantify the collagen from the mantis shrimp, a fishery resource obtained as a by-catch from fisheries.

\section{Materials and Methods}

In this study, collagen was extracted from the muscles of four mantis shrimp species, namely the three-banded mantis shrimp (Miyakella nepa), the giant mantis shrimp (Harpiosquilla harpax), the blue-tailed mantis shrimp (Erugosquilla woodmasoni), and the purple-tailed mantis shrimp (Odontodactylus cultrifer), and the amount of pepsin-soluble collagen (PSC) was compared. Samples were taken from the M.V. SEAFDEC2 survey ship (211 gross tonnage) (Fig. 1) by Trawl Net. The number of mantis shrimp in the project titled "Collaborative research survey on marine fisheries resources and marine environment in the gulf of Thailand" was approximately $10 \%$ of the total number of marine crustacean animals collected $(n=79)$. The samples were stored in the vessel freezer until the end of the survey and kept at $4{ }^{\circ} \mathrm{C}$ during transfer to the experimental laboratory.

\section{Collagen extraction}

Before the calcium removal step, the muscles of all four species of mantis shrimp were cut into a small pieces and $20 \mathrm{~g}$ samples were accurately weighed $(n=3)$. The positive control group comprised $20 \mathrm{~g}$ of the pooled muscles of the four species of mantis shrimp ( $5 \mathrm{~g}$ of each mantis shrimp species). The samples were incubated at $30^{\circ} \mathrm{C}$ overnight for drying and then treated with $1.2 \mathrm{~N} \mathrm{HCl}$ at a sample to acid solution ratio of 1:6 (w/v) at $25^{\circ} \mathrm{C}$ for $6 \mathrm{~h}$ with constant stirring. Then, the samples were rinsed repeatedly with distilled water until a neutral $\mathrm{pH}$ (7.0) of the solution was reached. The samples were then treated with 0.1 $\mathrm{N} \mathrm{NaOH}$ at a sample to alkali solution ratio of $1: 5(\mathrm{w} / \mathrm{v})$ at $25^{\circ} \mathrm{C}$ 


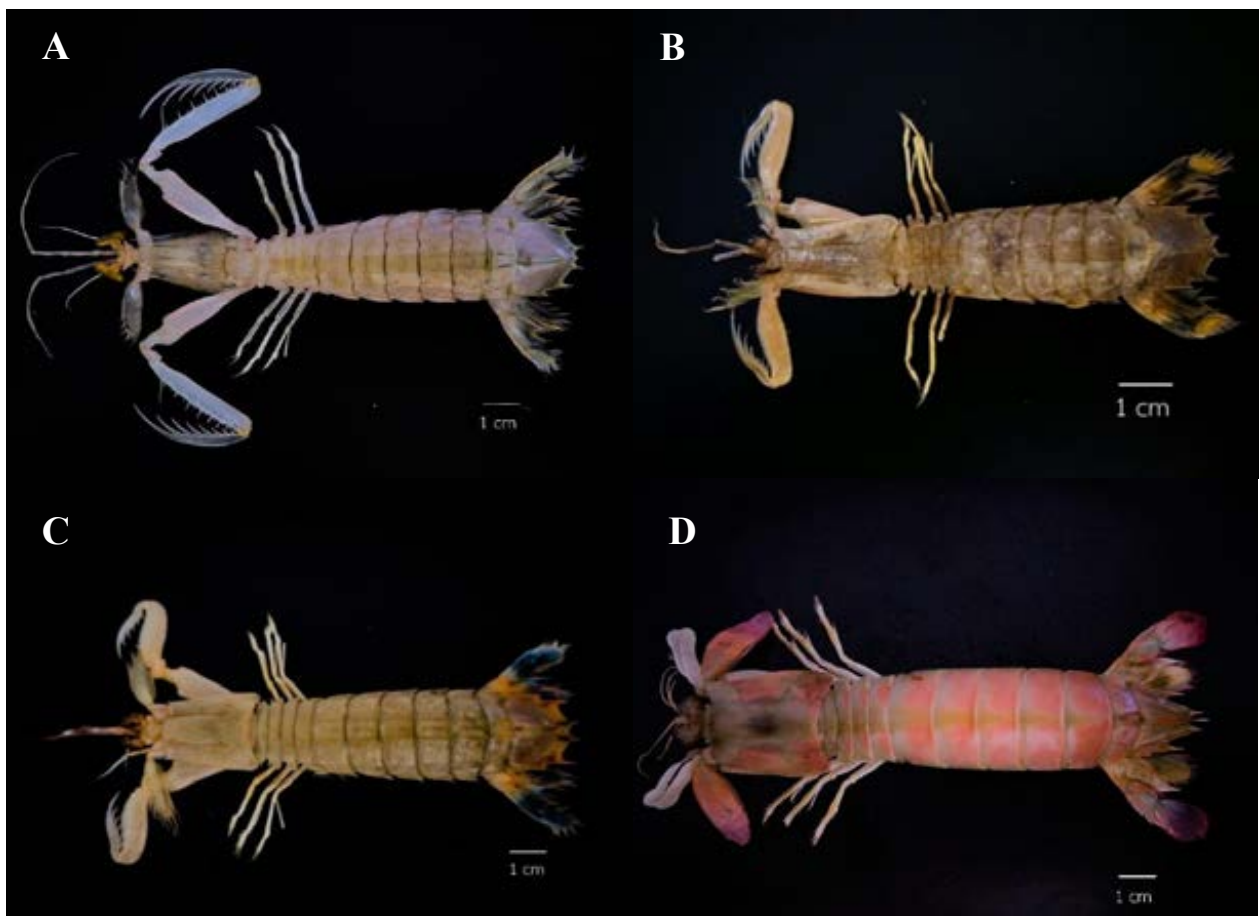

Fig. 1. The four species of mantis shrimp used in this study: Harpiosquilla harpax (A), Miyakella nepa (B), Erugosquilla woodmasoni (C), and Odontodactylus cultrifer (D).

for $6 \mathrm{~h}$ with constant stirring to remove the noncollagenous proteins and pigments. The solution was changed every $2 \mathrm{~h}$. The samples were then rinsed repeatedly with distilled water until a neutral $\mathrm{pH}$ was reached.

To extract the PSC, the deproteinized samples were treated with $0.5 \mathrm{M}$ acetic acid $(\mathrm{pH} 2.5)(1: 5 \mathrm{w} / \mathrm{v})$ with $5 \%$ pepsin at a sample to pepsin ratio of 10:0.5 (w/v) for $72 \mathrm{~h}$ with constant stirring. The samples were filtered through filter paper and the solution was then centrifuged at $20,000 \times \mathrm{g}$ for $30 \mathrm{~min}$ at $4{ }^{\circ} \mathrm{C}$ to remove the residues. Collagen was isolated from the supernatant by precipitation in $0.9 \mathrm{M} \mathrm{NaCl}$ and then centrifuged at $20,000 \times \mathrm{g}$ for $45 \mathrm{~min}$ at $4^{\circ} \mathrm{C}$. The supernatant was removed and the residue was then dissolved in $0.5 \mathrm{M}$ acetic acid (1:4 w/ v). The collagen solution was dialyzed in deionized water to remove the acid solution for $24 \mathrm{~h}$, with water changes every 6 h. The percentage yield of PSC for each sample was determined from the following equation: yield $(\%)=$ (weight of collagen/ dried weight of mantis shrimp muscle) $\times 100$.

\section{Statistical analysis}

The data were presented as the mean \pm SD of three replicate analyses. Statistical analyses were performed using one-way
ANOVA and Student's $t$-test. Multiple comparisons of the means were performed using the LSD test. A probability value of $<0.05$ was considered significant. All computations were made using R-Studio (for Windows).

\section{Study of collagen subunits by gel electrophoresis}

The concentration of collagen was determined spectrophotometrically using a bovine serum albumin (BSA) assay (Bradford, 1976) in conjunction with an appropriate standard curve. The collagen subunits were then analyzed using sodium dodecyl sulfate-polyacrylamide gel electrophoresis (SDS-PAGE) in accordance with the method of Laemmli (1970). The collagen solutions were prepared, mixed with sample buffer in a 1:1 ratio, and boiled in at $95^{\circ} \mathrm{C}$ for $5 \mathrm{~min}$. The protein was loaded onto a 5\% polyacrylamide gel stacking gel and separated through a $10 \%$ polyacrylamide running gel by electrophoresis ( $100 \mathrm{~V}, 50$ $\mathrm{mA}$, approximately $2 \mathrm{~h}$ ). The gel was stained with Coomassie blue R-250 for 12-15 min, and washed with distilled water for approximately $1 \mathrm{~h}$ or until a clear protein band was visible. The gel was then photographed and the staining was quantified using laboratory imaging software (Gel Doc, Bio-RAD, Hercules, CA, USA). 


\section{Analysis of collagen using Fourier transform-infrared (FT-IR) spectroscopy}

Freeze-dried collagen samples were prepared into discs containing $1 \mathrm{mg}$ of the sample in approximately $100 \mathrm{mg}$ of potassium bromide (KBr), and analyzed using an FT-IR spectrophotometer (OMNIC Picta). The spectra were recorded within the range of $400-4,000 \mathrm{~cm}^{-1}$ with a $4 \mathrm{~cm}^{-1}$ spectral resolution and the spectral format was selected as \%Transmittance. The FT-IR spectra of the standard type I collagen (Jose et al., 2014) were used for predication and confirmation of the secondary structure of collagen.

\section{Collagen solubility test}

The solubility of collagen was determined using the methods of Jongjareonrak et al. (2005), with slight modification. The collagens were dissolved in $0.5 \mathrm{M}$ acetic acid solution to obtain a final concentration of $3 \mathrm{mg} / \mathrm{mL}$ (for the $\mathrm{pH}$ test) and $6 \mathrm{mg} / \mathrm{mL}$ (for the $\mathrm{NaCl}$ test) and the mixture was stirred at $4{ }^{\circ} \mathrm{C}$ until the collagen was completely solubilized and no pellet was observed after a 10-min settlement period.

\section{Effect of $\mathrm{pH}$ on collagen solubility}

Samples of $8 \mathrm{~mL}$ of collagen solution $(3 \mathrm{mg} / \mathrm{mL})$ were placed in a $15-\mathrm{mL}$ centrifuge tube and adjusted to the $\mathrm{pH}$ values of $1,3,5$, and 7 with $6 \mathrm{~N} \mathrm{HCl}$ or $6 \mathrm{~N} \mathrm{NaOH}$, a dilution series was prepared, and the volume was made up to $10 \mathrm{~mL}$ with distilled water. The solutions were centrifuged at $10,000 \times \mathrm{g}$ for $30 \mathrm{~min}$ at $4{ }^{\circ} \mathrm{C}$. The protein concentration of the supernatant was determined by the Bradford assay (1976) using BSA as a standard. The relative solubility of the protein was calculated from the following equations: Solubility $=$ (protein content of the supernatant/total protein content in the sample) $\times 100$; Relative solubility $=($ solubility at a given $\mathrm{pH} /$ the highest solubility in the range of $\mathrm{pH}) \times 100$.

\section{Effect of $\mathrm{NaCl}$ on collagen solubility}

Five milliliters of collagen $(6 \mathrm{mg} / \mathrm{mL})$ in $0.5 \mathrm{M}$ acetic acid were mixed with $5 \mathrm{~mL}$ of cold $\mathrm{NaCl}$ in $0.05 \mathrm{M}$ acetic acid at various concentrations of 0,2 , and $4(\% \mathrm{w} / \mathrm{v})$ and the mixture was stirred for $30 \mathrm{~min}$ at $4{ }^{\circ} \mathrm{C}$. Thereafter, the same process was then used for the $\mathrm{pH}$ solubility study.

\section{Results and Discussion}

\section{Collagen yields}

PSC was extracted from the muscle of four species of mantis shrimp: M. nepa, H. harpax, E. woodmasoni, and O. cultrifer (Fig. 1). During the removal of calcium by hydrochloric acid solution, the collagen pieces turned a milky-pink color. After the calcium was removed, the texture was softer and opaque white in color. After calcium removal, the sample wet weight was approximately $3-5 \mathrm{~g}$. The pigment and non-collagenous proteins were then removed. The color of the sample during the removal of other proteins and pigments was clear, jelly-like, and soft, with a residual wet weight of approximately 1-2 g (Fig. 2). The collagen was freeze-dried and the percentage yield of the collagen extract was calculated. The highest collagen yield was obtained from M. nepa $(0.478 \pm 0.06 \%)$; this was significantly higher than that of H. harpax, O. cultrifer, and E. woodmasoni $(0.313 \pm 0.03 \%, 0.123 \pm 0.02 \%$, and $0.015 \pm 0.00 \%$, respectively) $(p<0.05)$ (Table 1). The collagen content in the muscle of mantis shrimp $M$. nepa in this study was in accordance with the previously reported by Mizuta et al. (1994) reported that the collagen content in the muscles of shrimp and mantis shrimp was relatively high $(0.31 \%-0.58 \%$ by weight of muscle). These values were higher than other crustaceans compared with marine crabs $(0.04 \%-0.09 \%$ by weight). When observed under light microscopy, the shrimp muscles had a dense distribution of collagen fibers and the muscles of the crab were sparsely distributed. These factors played an important role in determining consumer satisfaction with the taste of crustacean meat in tropical areas. Hydroxyproline, which is involved in inter-chain hydrogen bonding, stabilizes the triple helical structure of collagen. Therefore, collagens derived from aquatic species living in cold environments have lower proportions of hydroxyproline and exhibit lower thermal stability than those from aquatic species living in warm environments (Tabarestani et al., 2012). This

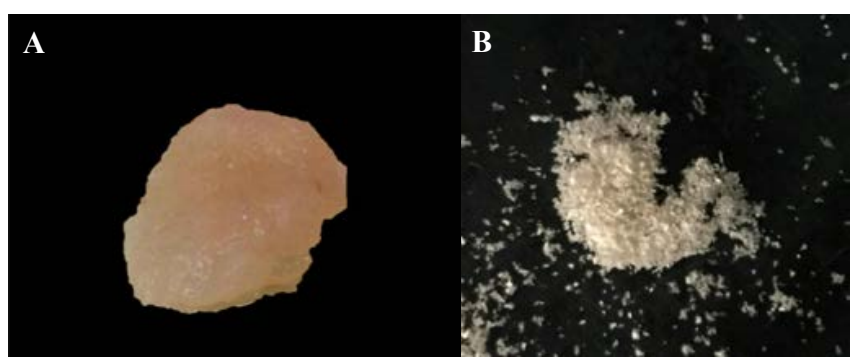

Fig. 2. Appearance of mantis shrimp meat after the calcification process and the removal of noncollagenous proteins $(A)$ and the characteristics of collagen powder after freeze drying process (B). 
Table 1. Weight of mantis shrimp sample after the collagen extraction process and yield (\%) of collagen

\begin{tabular}{|c|c|c|c|c|c|}
\hline Mantis shrimp species & $\begin{array}{l}\text { Weight after drying } \\
\text { (g) }\end{array}$ & $\begin{array}{l}\text { Weight after calcium } \\
\text { removal (g) }\end{array}$ & $\begin{array}{l}\text { Weight after removal of noncollagenous } \\
\text { material (g) }\end{array}$ & $\begin{array}{l}\text { Freeze dried of collagen } \\
\quad(\mathrm{mg})\end{array}$ & $\begin{array}{l}\text { Yield } \\
(\%)\end{array}$ \\
\hline Miyakella nepa & $2.686 \pm 0.37^{\mathrm{a}}$ & $4.829 \pm 0.76^{\text {abc }}$ & $2.000 \pm 0.40^{b}$ & $12.7 \pm 0.018^{d}$ & $0.478 \pm 0.06^{d}$ \\
\hline Harpiosquilla harpax & $3.125 \pm 0.33^{\mathrm{a}}$ & $5.042 \pm 0.84^{\mathrm{bc}}$ & $2.421 \pm 0.14^{\mathrm{bc}}$ & $9.7 \pm 0.009^{c}$ & $0.313 \pm 0.03^{c}$ \\
\hline Erugosquilla woodmasoni & $3.336 \pm 0.10^{\mathrm{a}}$ & $2.715 \pm 0.65^{\mathrm{a}}$ & $1.280 \pm 0.18^{\mathrm{a}}$ & $5.0 \pm 0.001^{\mathrm{a}}$ & $0.015 \pm 0.00^{\mathrm{a}}$ \\
\hline Odontodactylus cultrifer & $4.281 \pm 0.58^{\mathrm{b}}$ & $5.879 \pm 2.19^{c}$ & $1.868 \pm 0.2^{6 b}$ & $5.2 \pm 0.003^{b}$ & $0.123 \pm 0.02^{b}$ \\
\hline
\end{tabular}

${ }^{a-d}$ Characters that differ in the same column represent statistically significant differences $(p<0.05)$.

is extremely important information that supports the utilization and value of by-catch animals, such as mantis shrimp, for the commercial production of collagen.

Pepsin-acetic acid extraction is the second primary method for collagen extraction, and employs an enzymatic pretreatment of pepsin to digest the telopeptide ends of the collagen chains to facilitate the removal of proteins from the remaining matrix. This facilitated the leaching of collagen peptides in solution and increased the extraction yield (Ahmed et al., 2019). In this study, $0.5 \mathrm{M}$ acetic acid with $5 \%$ pepsin was used to extract collagen from mantis shrimp muscle in accordance with our previous research in Greenback mullet (Liza subviridis) (Kutako et al., 2016). Increasing the pepsin concentration can cause a major increase in the isolation yield; however, the cost of extraction process also increases. Furthermore, the net yield on the dry weight basis of $42 \%$ of acid-soluble collagen (ASC) and $23 \%$ of PSC from the body muscles of mantis shrimp Oratosquilla nepa has been reported (Jose et al., 2014).

\section{SDS-PAGE analysis of collagens from mantis shrimp muscle}

The collagens extracted from the mantis shrimp muscle were analyzed by SDS-PAGE (Fig. 3). The electrophoretic patterns and migration of collagens from M. nepa, H. harpax, O. cultrifer, and E. woodmasoni muscle were similar, comprising at least two different $\alpha$ chains, $\alpha 1$ and $\alpha 2$, and clearly identifiable $\beta$ (dimer) chains. From these results, it was suggested that collagens from the mantis shrimp muscle were type I collagens with a heteropolymer of one $\beta$ chain, one $\alpha 1$ chain, and one $\alpha 2$ chain. The average molecular weights of the collagen subunits for the $\beta$, $\alpha 1$, and $\alpha 2$ chains was approximately 250,145 , and $105 \mathrm{kDa}$, respectively. However, the a chain molar ratio ( $11 / \alpha 2)$ of collagen subunits in O. cultrifer and E. woodmasoni was slightly higher than in other species.

From the SDS-PAGE results of collagen in the present study, it was suggested that collagens from mantis shrimp muscle were type I collagens by the appearance of one $\beta$ chain, one

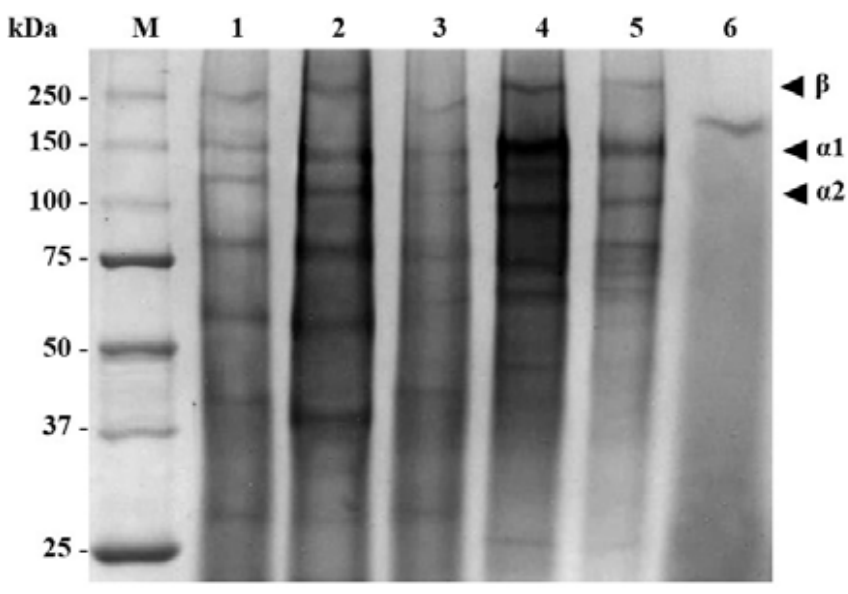

Fig. 3. SDS-PAGE analysis showed the characteristics of collagen patterns in extracts of the meat from different species of mantis shrimp. Lane 1, standard protein; Lane 2, collagen extracted from pooled muscles of four mantis shrimp species; Lanes 3-6, collagen extracted from Miyakella nepa; Harpiosquilla harpax; Odontodactylus cultrifer, and Erugosquilla woodmasoni muscles; Lane 7, commercial collagen from marine fish. SDS-PAGE, sodium dodecyl sulfate-polyacrylamide gel electrophoresis.

a1 chain, and one $\alpha 2$ chain (approximately 250, 145, and 105 $\mathrm{kDa}$, respectively) (Table 2 and Fig. 3). Type I collagen is the main component in all connective tissue, including bone and skin (Ciarlo et al., 1997; Montero et al., 1990; Nagai \& Suzuki, 2000) and has functions that include the mechanical protection of tissues and organs or the physiological regulation of the cell environment. The protein patterns and migration of collagens in this study were in accordance with the patterns of type I collagen from the muscle of O. nepa as reported by Jose et al. (2014).

Type I collagen has been reported in both aquatic vertebrates and invertebrates (Ahmed et al., 2019; Cheng et al., 2017; Duan et al., 2009; Jongjareonrak et al., 2005; Jose et al., 2014; Khong et al., 2018; Pati et al., 2010; Tziveleka et al., 2017; Veeruraj et al., 2015 ). The high molecular weight and richness of 
Table 2. Comparison of molecular weights of type I collagens: $\beta, \alpha 1$, and $\alpha 2$ subunits found in this study

\begin{tabular}{llll}
\hline Species of sample & \multicolumn{3}{l}{ Collagen Type I (kDa) } \\
\cline { 2 - 4 } & $\beta$ & $\mathrm{a} 1$ & $\mathrm{a} 2$ \\
\hline Miyakella nepa & 250 & 139 & 111 \\
Harpiosquilla harpax & $\sim 250$ & 142 & 113 \\
Odontodactylus cultrifer & 250 & 148 & 100 \\
Erugosquilla woodmasoni & 250 & 150 & 100 \\
\hline
\end{tabular}

inter- and intra-molecular crosslinked components of collagen were found to increase as the age of the animal increased. Higher molecular weight collagen with a greater degree of crosslinking was found in starved animals compared with well-fed animals (Foegeding et al., 1996).

\section{Collagen analysis using FT-IR spectroscopy}

The FT-IR spectra of PSC from the four species of mantis shrimp are shown in Fig. 4. Collagen from fish skin was used as a standard compound to identify the characteristic peaks of collagen. Five major bands, which are characteristic of amides (amides A, B, I, II, and III) were found in the four species of mantis shrimp collagen type I at wavelengths of 3,406-3,421, $2,916-2,940,1,639-1,640,1,539-1,570$, and 1,234-1,250 $\mathrm{cm}^{-1}$, respectively. These characteristic peaks were present in the FTIR spectra, but the values were slightly shifted.

The FT-IR regions for amides I, II, and III are known to be directly related to the nature of a polypeptide. The presence of amide I band, with characteristic frequencies in the range from $1,600-1,660 \mathrm{~cm}^{-1}$, is mainly associated with stretching vibrations of the carbonyl groups along the polypeptide backbone, and this is the most important factor for understanding the secondary structure of a protein (Saallah et al., 2021). The existence of collagen triple helical structures was confirmed by the presence of amide II and III bands. Amide II is associated with $\mathrm{NH}$ bonding and $\mathrm{CN}$ stretching, and amide III is related to $\mathrm{CN}$ stretching and $\mathrm{NH}$ and is involved with the triple helical structure of collagen. The ratio of the absorption intensity between the 1,220-1,320 $\mathrm{cm}^{-1}$ (amide III) and $~ 1,550 \mathrm{~cm}^{-1}$ (amide II) bands, which was approximately equal to 1.0 , confirmed the triple helical structure of collagen from the muscle of mantis shrimp (Plepis et al., 1996). The results from this present study revealed all the amide regions of A, B, I, II, and III for each collagen (Table 3).

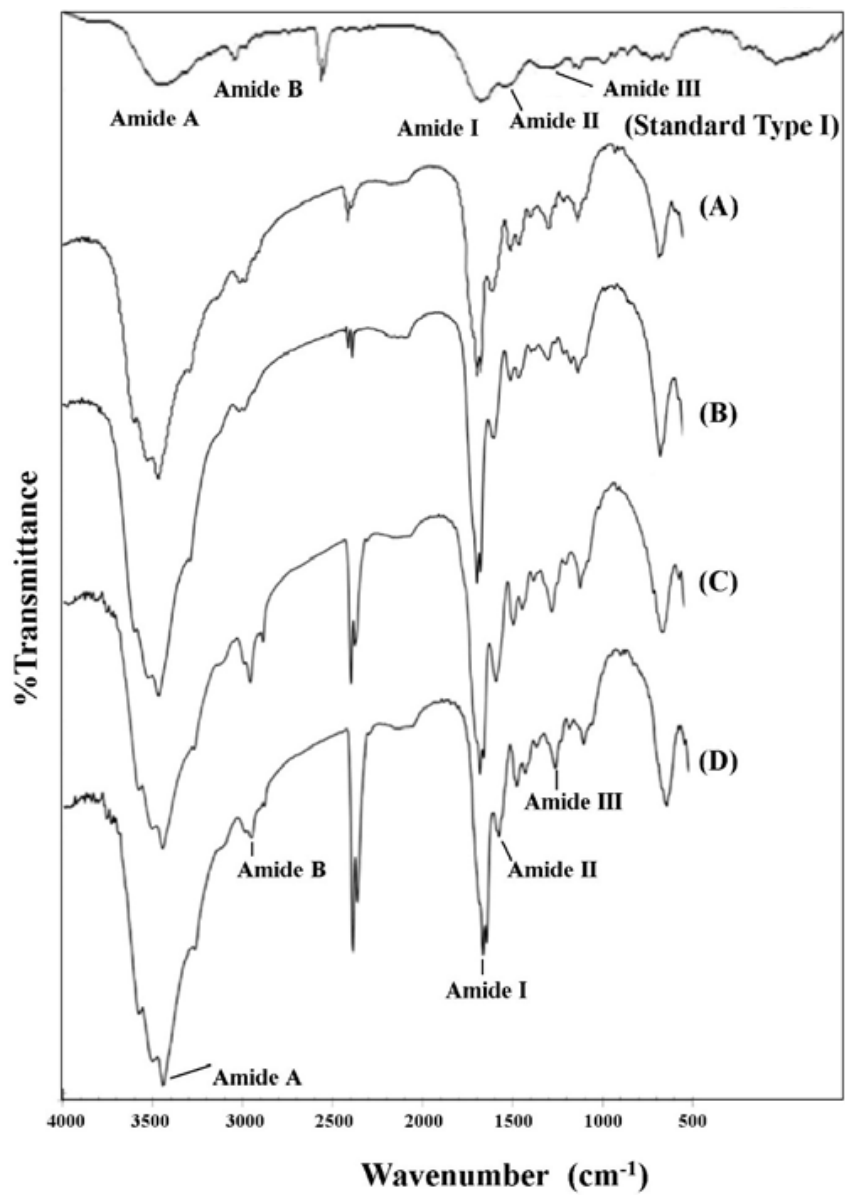

Fig. 4. FT-IR spectra of collagens from Harpiosquilla harpax (A), Miyakella nepa (B), Erugosquilla woodmasoni (C), and Odontodactylus cultrifer (D) showed the five major amides in comparison with the FT-IR spectra of the standard type I collagen. Adapted from Jose et al. (2014) with CC-BY . FT-IR, Fourier transform-infrared.

\section{Effect of $\mathrm{pH}$ and $\mathrm{NaCl}$ on collagen solubility}

The solubility of collagen in the muscles of $M$. nepa was tested under different $\mathrm{pH}$ and $\mathrm{NaCl}$ concentrations. High solubility was observed in very acidic $\mathrm{pH}$ ( 1 to 3 ) and there was a sudden precipitation from solubility at neutral pH (Fig. 5A). Solubility was highest at $\mathrm{pH} 3$, with a relative solubility of $91.32 \pm$ $5.14 \%$. A similar result was reported for the pepsin solubility of collagen from the body wall of the sea cucumber Acaudina leucoprocta where the maximum solubility was recorded at $\mathrm{pH}$ 2.66 (Lin et al., 2017). Generally, collagens are more soluble in acidic $\mathrm{pH}$ environments. The isoelectric point ( $\mathrm{pI}$ ) of collagen is between pH 6 and 7 (Foegeding et al., 1996). A protein can be dissolved in buffer at its isoelectric point; the hydrophobic inter- 
Table 3. The major peaks, functional group, and wavenumber $\left(\mathrm{cm}^{-1}\right)$ in the FT-IR spectra for collagen isolated from four species of mantis shrimp

\begin{tabular}{lll}
\hline Wavenumber $\left(\mathrm{cm}^{-1}\right)$ & Functional group & Mantis shrimp species \\
\hline $3,400-3,440$ & $\mathrm{~N}-\mathrm{H}$ stretching vibrations (amide A) & $3,406-3,421$ \\
$2,840-3,000$ & $\mathrm{C}-\mathrm{H}$ stretching (amide B-alkane) & $2,916-2,940$ \\
2,349 & $\mathrm{O}=\mathrm{C}=\mathrm{O}$ stretching (carbon dioxide) & $2,334-2,361$ \\
$1,600-1,660$ & Associate with stretching vibrations of carbonyl group in peptides (amide I) & $1,639-1,640$ \\
$\sim 1,550$ & Associate with NH bonding and CN stretching (amide II) & $1,539-1,570$ \\
$1,330-1,420$ & O-H bending (alcohol) & $1,396-1,460$ \\
$1,220-1,320$ & CN stretching and NH and it is involved with the triple helical structure of collagen (amide III) & $1,234-1,250$ \\
$1,000-1,300$ & C-O stretching (ester and ether) & $1,076-1,084$ \\
$600-800$ & C-Cl (chloride compound) & $609-625$ \\
\hline
\end{tabular}

FT-IR, Fourier transform-infrared.

(A)

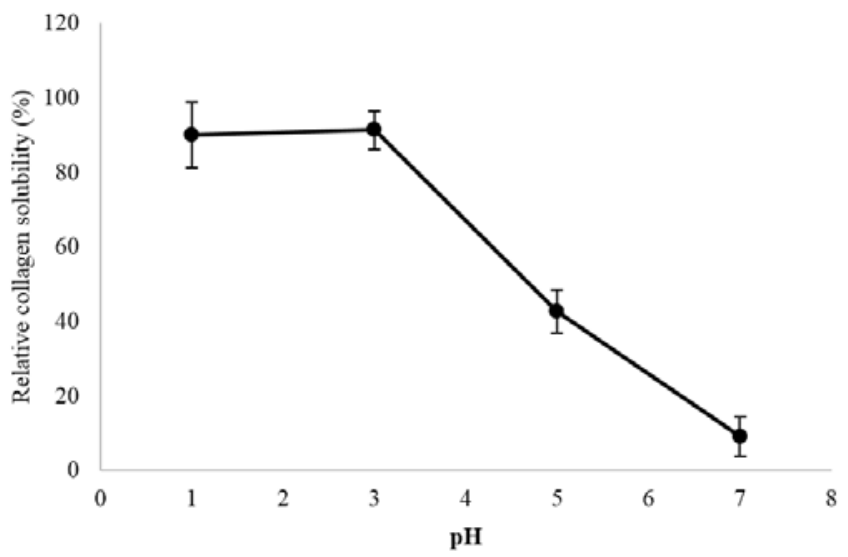

(B)

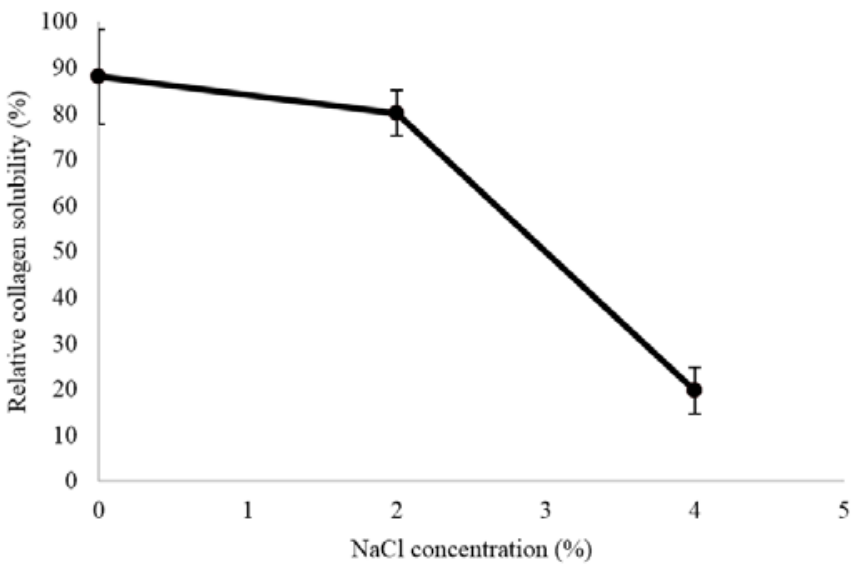

Fig. 5. Graph showing the relative solubility of collagen from mantis shrimp muscles at different $\mathrm{pH}(\mathrm{A})$ and $\mathrm{NaCl}(\mathrm{B})$ concentrations.

actions between molecules have reached a maximum, and protein precipitation and aggregation are induced (Liu et al., 2010). For $\mathrm{pH}$ below or above the isoelectric point, the net negative or positive charge residues of protein molecules is increased and the static repulsion forces between the peptide chains lead to partial protein solubility (Kittiphattanabawon et al., 2005).

The PSC solubility in $0.5 \mathrm{M}$ acetic acid was highest at $2 \%$ $\mathrm{NaCl}$, corresponding to a relative stability of $80.20 \pm 4.95 \%$, but dramatically decreased when the $\mathrm{NaCl}$ concentration was increased to $4 \%$ (Fig. 5B). The precipitation was caused by the salting-out effect on the protein structure. The PSC from the mantis shrimp had similar sensitivity to $\mathrm{NaCl}$ as PSC from the sea cucumber A. leucoprocta (Lin et al., 2017).

This increases the ionic strength, causing the hydorphobic areas in protein chains to more with each other. The proteins then coagulate and precipitate, where they separate from the solution. This phenomenon is called "salting out" (Vojdani, 1996). However, collagen solubility is also influenced by the protein conformations and molecular properties (Kittiphattanabawon et al., 2005). In this study, the $\mathrm{pH}$ and $\mathrm{NaCl}$ solubility study demonstrated that the PSC from the mantis shrimp muscle was similar to the other species of invertebrate, such as sea cucumber and surf clam shell, but slightly different to that from fishes (Jafari et al., 2020; Liu et al., 2010). This may be caused by the molecular composition and conformations of collagens. In addition, the collagens extracted from different species and by methods may generate different molecular properties that result in the varying solubility of collagens. 


\section{Conclusion}

PSC from the muscles of four species of mantis shrimp ( $M$. nepa, H. harpax, O. cultrifer, and E. woodmasoni) has been successfully isolated. SDS-PAGE confirmed that PSC of the mantis shrimp was type I collagen, which contained $\beta, \alpha 1$, and $\alpha 2$ subunits. The solubility of collagen at different $\mathrm{pH}$ and $\mathrm{NaCl}$ concentrations was investigated. The highest solubility of collagen type I from the muscle of mantis shrimp occurred at $\mathrm{pH} 3$ and $2 \% \mathrm{NaCl}$. The FT-IR spectra of the collagen type I from four species of mantis shrimp consisted of five major bands, characterized as amides A, B, I, II, and III. In fisheries, the mantis shrimp is a by-catch marine species that has become economically important for aquaculture in Asia, including Thailand. The isolation of collagen from mantis shrimp may serve as an alternative source of mammalian collagen for potential biomedical and pharmaceutical applications in various sectors, including foods, pharmaceuticals, nutraceuticals, and cosmetics. Therefore, it is possible to increase the value of by-catch marine species by using it as an alternative source of collagen.

\section{Competing interests}

No potential conflict of interest relevant to this article was reported.

\section{Funding sources}

The samples for this research was provided by Southeast Asian Fisheries Development Center (SEAFDEC) under the research project titled "Collaborative research survey on marine fisheries resources and marine environment in the gulf of Thailand".

\section{Acknowledgements}

Special thanks to Faculty of Gems and Faculty of Marine Technology, Burapha University for providing facilities and research equipment.

\section{Availability of data and materials}

Upon reasonable request, the datasets of this study can be available from the corresponding author.

\section{Ethics approval and consent to participate}

The main research project researcher of this study was approved for animal ethics by Institute of animals for scientific purposes development (IAD), Thailand (Animal used license U1-036312559, National Level).

\section{ORCID}

RachanimukHiransuchalert https://orcid.org/0000-0002-7929-2100

Nakaweerada Oonwiset https://orcid.org/0000-0002-3689-9017 Yolrawee Imarom https://orcid.org/0000-0001-8337-1939 Parinya Chindudsadeegul https://orcid.org/0000-0003-3898-8694 Penchan Laongmanee https://orcid.org/0000-0001-6064-7509 Sukchai Arnupapboon https://orcid.org/0000-0003-4922-4905

\section{References}

Ahmed R, Haq M, Chun BS. Characterization of marine derived collagen extracted from the by-products of bigeye tuna (Thunnus obesus). Int J Biol Macromol. 2019;135:668-76.

Bradford MM. A rapid and sensitive method for the quantitation of microgram quantities of protein utilizing the principle of protein-dye binding. Anal Biochem. 1976;72:248-54.

Cheng X, Shao Z, Li C, Yu L, Raja MA, Liu C. Isolation, characterization and evaluation of collagen from jellyfish Rhopilema esculentum kishinouye for use in hemostatic applications. PLOS ONE. 2017;12:e0169731.

Ciarlo AS, Paredi ME, Fraga AN. Isolation of soluble collagen from hake skin (Merluccius hubbsi). J Aquat Food Prod Technol. 1997;6:65-77.

Duan R, Zhang J, Du X, Yao X, Konno K. Properties of collagen from skin, scale and bone of carp (Cyprinus carpio). Food Chem. 2009;112:702-6.

Foegeding EA, Lanier TC, Hultin HO. Collagen. In: Fennema OR, editor. Food chemistry. 3rd ed. New York, NY: Marcel Dekker; 1996. p. 902-6.

Jafari H, Lista A, Siekapen MM, Ghaffari-Bohlouli P, Nie L, Alimoradi $\mathrm{H}$, et al. Fish collagen: extraction, characterization, and applications for biomaterials engineering. Polymers. 2020;12:1-37.

Jongjareonrak A, Benjakul S, Visessanguan W, Nagai T, Tanaka M. Isolation and characterisation of acid and pepsin-solubilised collagens from the skin of Brownstripe red snapper (Lutjanus vitta). Food Chem. 2005;93:475-84.

Jose HMPM, Murugesan P, Arumugam M, Kumar KM. Isolation and characterization of acid and pepsin-solubilised collagen from the muscle of mantis shrimp (Oratosquilla nepa). Int J Pharm Pharm Sci. 2014;6:654-7.

Khong NMH, Yusoff FM, Jamilah B, Basri M, Maznah I, Chan $\mathrm{KW}$, et al. Improved collagen extraction from jellyfish (Acromitus hardenbergi) with increased physical-induced solubilization processes. Food Chem. 2018;251:41-50. 
Kittiphattanabawon P, Benjakul S, Visessanguan W, Nagai T, Tanaka M. Characterisation of acid-soluble collagen from skin and bone of bigeye snapper (Priacanthus tayenus). Food Chem. 2005;89:363-72.

Kutako M, Tocharoen T, Sonthi M, Hiransuchalert R, Watanachote J. Yield and protein pattern of collagen extracted from Greenback mullet (Liza subviridis) scale by different pepsin concentrations. Khon Kaen Agric J. 2016;43:562-7.

Laemmli UK. Cleavage of structural proteins during the assembly of the head of bacteriophage T4. Nature. 1970;227:680-5.

Lin S, Xue YP, San E, Keong TC, Chen L, Zheng YG. Extraction and characterization of pepsin soluble collagen from the body wall of sea cucumber Acaudina leucoprocta. J Aquat Food Prod Technol. 2017;26:502-15.

Liu Z, Oliveira ACM, Su YC. Purification and characterization of pepsin-solubilized collagen from skin and connective tissue of giant red sea cucumber (Parastichopus californicus). J Agric Food Chem. 2010;58:1270-4.

Meyer M. Processing of collagen based biomaterials and the resulting materials properties. Biomed Eng Online. 2019;18:1-74.

Mizuta S, Yoshinaka R, Sato M, Sakaguchi M. Characterization of collagen in the muscle of several crustacean species in association with raw meat texture. Fish Sci. 1994;60:323-8.

Montero P, Borderias J, Turnay J, Leyzarbe MA. Characterization of hake (Merluccius merluccius L.) and trout (Salmo irideus Gibb) collagen. J Agric Food Chem. 1990;38:604-9.

Morimura S, Nagata H, Uemura Y, Fahmi A, Shigematsu T, Kida K. Development of an effective process for utilization of collagen from livestock and fish waste. Process Biochem. 2002;37:1403-12.

Nagai T, Suzuki N. Isolation of collagen from fish waste material — skin, bone and fins. Food Chem. 2000;68:277-81.

Pati F, Adhikari B, Dhara S. Isolation and characterization of fish scale collagen of higher thermal stability. Bioresour Technol. 2010;101:3737-42.

Plepis AMDG, Goissis G, Das-Gupta DK. Dielectric and pyroelectric characterization of anionic and native collagen. Polym Eng Sci. 1996;36:2932-8.

Saallah S, Roslan J, Julius FS, Saallah S, Mohamad Razali UH, Pindi W, et al. Comparative study of the yield and physicochemical properties of collagen from sea cucumber (Holothuria scabra), obtained through dialysis and the ultrafiltration membrane. Molecules. 2021;26:2564.
Sadowska M, Kołodziejska L, Niecikowska C. Isolation of collagen from the skins of Baltic cod (Gadus morhua). Food Chem. 2003;81:257-62.

Shoulders MD, Raines RT. Collagen structure and stability. Annu Rev Biochem. 2009;78:929-58.

Tabarestani HS, Maghsoudlou Y, Motamedzadegan A, Sadeghi Mahoonak AR, Rostamzad H. Study on some properties of acid-soluble collagens isolated from fish skin and bones of rainbow trout (Onchorhynchus mykiss). Int Food Res J. 2012;19:251-7.

Tziveleka LA, Ioannou E, Tsiourvas D, Berillis P, Foufa E, Roussis V. Collagen from the marine sponges Axinella cannabina and Suberites carnosus: isolation and morphological, biochemical, and biophysical characterization. Mar Drugs. 2017;15:152.

Veeruraj A, Arumugam M, Ajithkumar T, Balasubramanian T. Isolation and characterization of collagen from the outer skin of squid (Doryteuthis singhalensis). Food Hydrocoll. 2015;43:708-16.

Vojdani F. Solubility. In: Methods of testing protein functionality. London, UK: Blackie Academic \& Professional; 1996. p. 11-60. 